\title{
Corporate Director Independence, Actions and Ethics: A Survey
}

\author{
Ivan E. Brick \\ Rutgers University, USA \\ E-mail: ibrick@andromeda.rutgers.edu \\ N. K. Chidambaran (Corresponding author) \\ Fordham University, 1790 Broadway, \#1120, New York, NY 10019, USA \\ Tel: 1-646-312-8248Ｅ-mail: chidambaran@fordham.edu
}

Howard Tuckman

Fordham University, USA

Received: January 11, 2012

Accepted: February 12, 2012

Published: May 15, 2012

doi:10.5430/afr.v1n1p116

URL: http://dx.doi.org/10.5430/afr.v1n1p116

We would like to thank participants in our Director Survey for their cooperation. This research was supported in part by the Whitcomb Center for Research in Financial Services, Rutgers University and by a Faculty Research Grant from the Rutgers Business School - Newark and New Brunswick. It was also supported with funds from the a Faculty Research Grant at Fordham University. This paper is dedicated to the memory of Dr. Howard Tuckman.

\begin{abstract}
Recent financial events have raised questions whether social networks between directors and the firm can influence the actions of nominally independent directors. Using data from a national survey conducted in 2006-2007, we use measures based on the informal links between directors and firms to re-examine director independence. We define a board member to be independent if they did not know the CEO prior to becoming a director, was not nominated by a firm insider, and was not previously affiliated with the company. We find that the independent directors so defined are more likely to hold the CEO responsible for poor performance and less likely to receive much of their compensation from the directorship. They are also as likely as insider directors to express a concern about corporate citizenship and CEO ethical misconduct. Our survey shows that unmeasured networks between boards and management have an important bearing on the board's operation.
\end{abstract}

Keywords: Corporate governance, Director independence, Survey, Shareholder alignment, Social responsibility

\section{Introduction}

Corporate directors are tasked with the critical role of monitoring the senior management of public companies and have a fiduciary responsibility to protect shareholder interests. Major examples of fraud and failure such as the case of Enron and MCI-WorldCom have been seen to stem from a lack of director independence (see e.g. Blue Ribbon Committee 1999, Healy and Palepu 2003).Corporate governance reformists and regulators responded with an aggressive campaign to increase the independence of corporate boards, primarily with a view to break the nexus between the board and the CEO. Boards now largely meet the notional definition of independence established by the SEC, especially in the aftermath of the passage of the 2002 Sarbanes-Oxley Act with its requirement for independent Audit committees and increased director accountability. Nonetheless, calls to make boards more effective have not ceased, especially in light of the recent financial crisis.

We argue that an important aspect of CEO-Director relationships relevant to making directors more independent are the social networks that may exist between CEOs and Directors. Social networks are the links that form between CEOs and directors through networks and channels outside of the firm and prior to the director accepting a position with the firm. For example, it is quite plausible that the Director knew the CEO prior to being nominated to the board, from having gone to undergraduate schools together or meeting them at common attendance at cultural events as has been noted in the literature 
(see for example, Westphal 1999, Cohen, Frazzini, and Molloy 2008, 2010, and Chidambaran, Kedia, and Prabhala 2011). While the traditional measures of independence does not allow for direct family ties they do not measure such non-direct social connections. It remains an empirical issue whether such unmeasured attributes have any impact on director independence.

In this paper, we examine the role of social connections between directors and CEOs and its impact on the actions taken by directors using a broad national director survey conducted in 2006-2007. The director survey was conducted as follows. We designed a questionnaire aimed at discerning whether directors had ties to the CEO and the impact of these ties on their adherence to shareholder value maximization principles and the extent of their activities as a board member. The first portion of the survey was designed to solicit background information on the directors and their perception of skills needed for the job. The second portion of the survey was designed to solicit information on the nomination process and the extent to which the director had connections with the firm prior to their accepting the position. The third portion of the survey was designed to solicit information on the metrics that they would use to evaluate the CEO, the firm, and fellow directors. And finally, the fourth portion of the survey was designed to elicit information on the duties they performed as a director, the workload, and compensation.

We circulated the survey to a select group of directors to get their feedback and to ratify the questions we posed. Based on the feedback, we modified the questions to eliminate confusions and misinterpretations and to better elicit accurate responses. For example, we modified the instructions such that the individuals were directed to inform us whether they held multiple directorships but only respond to the questions with respect to the directorship that consumed most of their time. This ensured that the responses were for the most significant position they held. After the initial vetting process, the final survey questionnaire had 23 questions and is shown in the Appendix.

We mailed the questionnaire to directors using a mailing list obtained from The Corporate Library. We followed this up with a reminder to all directors in our original mailing list for whom we were able to obtain e-mail addresses from The Corporate Library. We received a total of 109 usable responses and we collated the responses to the individual questions.

The first goal of the survey was to classify directors as "independent" or "insider" based on the relationships between the director and the firm's management. Specifically our questionnaire asks whether: (a) the director was nominated by a firm insider, (b) the director knew the CEO before accepting their job, and (c) the director had a previous affiliation with the company. In each case the directors are classified as insider directors if they respond in the affirmative and are otherwise classified as independent. We also evaluate the impact of a stricter definition of independence when the director answers in the negative for all three questions. We find that between $25 \%$ and $67 \%$ of director respondents fall in any one of these categories.

We next analyze the impact of our definition of independence on the director's actions and test for the importance of social connections. Specifically, we examine whether social connections affect the importance of shareholder alignment and corporate citizenship/social responsibility factors in motivating actions a director has taken or would take. Our first test is motivated by the argument that the decision to replace the CEO is perhaps the single most important and traumatic decision for a board to undertake. We therefore examine the relative importance of shareholder return metrics and ethical considerations for replacing the CEO.

For our second set of tests we develop several different shareholder alignment measures to be used as a metric of the importance the director places on shareholder value. These measures are based on director responses to questions about the director's interest in shareholder value and the director's use of stock returns or cash flow to evaluate the firm and other directors. For example, we note a director as aligned if the director indicates that shareholder wealth maximization was an important reason to accept the job. For each alignment metric, we test for differences in the responses from independent directors and insider directors.

For our third set of tests, we develop several different corporate citizenship measures that proxy for the importance of social responsibility in determining director actions. There has been a tremendous increase in campaigns to increase awareness of a corporations social responsibility and it is of interest if independent directors responded differently to these campaigns compared to insider directors. Our tests are based on director responses to questions indicating the level of director's interest in corporate citizenship and the directors use of ethical criteria and corporate citizenship/ social responsibility metrics to evaluate the CEO. For each citizenship metric, we again test for differences in the responses by independent directors and insider directors.

We find that directors who are not nominated by insiders are more likely to hold the CEO responsible for poor performance as measured by either stock returns or accounting profits. We interpret this finding to imply that that social connections between a nominally independent director and the CEO do compromise their independence. We also find that 
directors who are not nominated by insiders are less likely to receive much of their compensation from the directorship. There seems to be some evidence that non-independent directors are coopted by the CEO and the firm as they receive more of their compensation from the firm. Our findings are consistent with that of Cohen, Frazzine, and Malloy $(2008,2010)$ who have found that social networks between analysts and mutual fund managers and the directors of firms have a strong impact on the actions of mutual fund managers and the performance of both mutual fund managers and analysts. Our findings are also consistent with findings of Chidambaran, Kedia, and Prabhala (2011) who have found that social networks between CEOs and directors impact on the probability of firms committing fraud.

The responses to the questions also indicate that directors hold ethical lapses by the CEO to be important. The importance of ethics is, however, not a function of director independence. Similarly, we also do not find any differences in the concern for corporate citizenship, as measured by our citizenship metrics, between independent and insider directors. Perhaps these results arise due to a positive cognitive bias given the discussions in popular press and news on the importance of enforcing ethical behavior and increasing awareness of the social responsibility of corporations.

Our survey and results shows that unmeasured board attributes with respect to the networks between boards and management have an important bearing on the board's operation and their monitoring and advising roles. These findings have important implications for the process by which directors are elected and the structure and composition of corporate boards. Our findings, for example, validate efforts to have director nominees provide detailed biographies to shareholders and report on affiliations with the firm, when they stand for election so that shareholders can be informed about some of these informal links.

The remainder of the paper is as follows. The next section summarizes the relevant literature. Section 3 presents the details of our survey and tabulates the responses. Section 4 presents the specific metrics we develop to measure we develop based on the survey to measure independence. Section 5 presents our analysis and results and Section 6 concludes.

\section{Literature Review}

The literature has found that board independence has important consequences for the firm. The logic behind electing independent directors is that those monitoring a company's senior management should make objective decisions free from conflicts of interest. Schaffer (2002) argues that outside and inside directors have different cognitive perspectives in evaluation of managerial performance. In particular, insider directors, either because of loyalty to the CEO or fear of dismissal will more likely attribute poor performance to outside factors beyond the control of the CEO. Weisbach (1988) finds that independent boards are more likely than other boards to replace poorly performing management. Byrd and Hickman (1992), and Cotter, Shivdasani, and Zenner (1997) demonstrate that independent boards are more likely to obtain larger merger bids for the target shareholders than non-independent boards. Beasley (1996), Klein (2002) and Chidambaran, Kedia, and Prabhala (2011) have found that as the number of independent outside directors on a board increases, the incidence of corporate fraud decreases. Roy (2009) survey of 161 Canadian companies also find that independent directors are much more involved in monitoring and the development of strategic policies than are inside directors. The literature thus suggests that independent directors play a shareholder-value-enhancing role, which has motivated much of the governance reform effort and the passage of the 2002 Sarbanes-Oxley Act and its provisions for director accountability.

The SEC and the Stock Exchanges have "legally" defined a director to be independent only if the director is not related to management and has no material relationship with the firm or its subsidiaries. While these prohibitions are useful, social ties between the CEO and independent directors add additional dimensions beyond the nominal notion of independence. Survey evidence also shows that CEOs exert substantial influence in the selection of new directors (Lorsch and MacIver 1989). Social connection between the director candidates can compromise the efficiency of the director or enhance their ability to give advice. Stevenson and Radin (2009) report on their survey of 14 firms that the social interaction of the board members with the $\mathrm{CEO}$ and other members of the board results in gaining greater influence in the decision making at the firm. Westphal's (1999) survey found that social connections between the board and the CEO would lead to more active involvement in strategic advice, and subsequent firm performance. These roles for directors are stressed in the "collaborative" board view of the board (see for example, Westphal (1999) and Adams and Ferreira (2007)).

Based on the literature on board independence and the importance of social connections, we propose and tests the following hypothesis with respect to the actions of the board based on our measures .

Hypothesis 1: Directors who are not socially connected to the CEO are independent and better aligned with shareholder value and will likely use stock returns to evaluate the CEO

Director independence can also affect the level compensation a director receives from their job. Brick, Palmon and Wald (2006) demonstrate empirically that board of director remuneration is highly correlated to that of the CEO. Warren Buffett 
in his 2006 Berkshire Hathaway Shareholder Letter also suggests that board compensation can be sufficiently high to affect independent judgments:

"In selecting a new director [Yahoo! CFO Susan Decker], we were guided by our long-standing criteria, which are that board members be owner-oriented, business-savvy, interested and truly independent. I say "truly" because many directors who are now deemed independent by various authorities and observers are far from that, relying heavily as they do on directors' fees to maintain their standard of living. These payments, which come in many forms, often range between $\$ 150,000$ and $\$ 250,000$ annually, compensation that may approach or even exceed all other income of the "independent" director."

We therefore propose and tests the following hypothesis with respect to the compensation and director-CEO social connections.

Hypothesis 2: Directors who are not socially connected to the CEO are better aligned with shareholder value and will likely have a smaller faction of their total income from the compensation they receive from their directorship.

Given the tremendous increase in campaigns to increase awareness of a corporations social responsibility, it is of interest whether independent directors responded differently to these campaigns compared to insider directors. In addition to the above two hypothesis, we therefore also examine the impact of the social connections on director's concern for corporate social responsibility and ethics. In particular, we want to test the following hypothesis:

Hypothesis 3: Directors who are not socially connected to the CEO are independent and do not differ from insider directors in their concern for corporate social responsibility and ethics.

\section{Survey Data}

Our survey was conducted in 2006-2007 and sent to over 5,500 corporate directors based on a national listing of names and addresses of directors provided by the Corporate Library. In a follow up mailing, we sent an additional 518 email requests to directors. Designed to collect information on their skills, educational level, reasons for joining a board, how they were nominated and related issues, the survey was pretested on several national directors for clarity, completeness, relevance, and accuracy and the instrument was refined to incorporate suggestions and changes and is shown in the Appendix. In total we received 109 usable responses (Note 1). The findings tallied from these surveys are the basis for the data presented below. Table 1 reports the summary statistics.

Insert Table 1 about here

The survey database contains 13 Chairmen, 6 Lead Directors, 2 Vice Chairmen, 71 Directors, 9 Audit Committee chairs, 2 CEOs, and 1 non-Audit Committee Chair. The directors in the survey are experienced and have served on the same board for a number of years. On average, directors spent an average of 9.6 years on the board included in our survey and have had 18.1 years of total board experience. In their survey responses, directors were asked to make their responses with respect to the board in which they spent most of their time to ensure that we have only one response from each director. Our approach keeps the focus on the characteristics of the most important, from the director's perspective, of an individual director's board experience.

The median director served 7 years on the board of the current survey, one year on a second board and has total board experience of 15 years. These data suggest that the median director has had substantial experience over time but did not serve simultaneously on multiple boards. The fact that directors stay on a board almost 10 years, on average, suggests a continuity of management over time but the possibility exists that board members may contribute less to management over time.

Our survey has a large number of directors with advanced degrees. For the 105 people who replied to the survey question regarding educational attainment, there are $21 \mathrm{PhDs}, 20 \mathrm{JDs}, 29$ Masters degree-holders, $1 \mathrm{MD}$, and $1 \mathrm{BA} / \mathrm{BS}$. These data seem to indicate that advanced education, particularly in the professions, is gaining in importance. Business, Finance and Accounting constitute about half of the degrees held by directors in our survey while Law represents about $19 \%$ of the total and Engineering about 9.5\%. Economics and Political Science represent another 8.6\% as do Science and Education $(4.8 \%)$.

The average board member has 6 out of a potential of 13 skills that we identified as important to the directors role. Strategic planning is overwhelmingly the most frequently found skill (89) followed by problem solving (77), financial analysis (75) and merger and acquisition (73). A small number of the Directors have advertising/marketing or lobbying 
/public relations (25), scientific training (19), or legal skills (21). Only about a third had regulatory compliance skills and a similar number claimed skills in competitor intelligence. Business skills are found in the backgrounds of many of the Directors and most relate to financial concepts and applications.

Approximately $56.1 \%$ of the board members were invited by senior management, $14.0 \%$ suggested by a search firm, $31.8 \%$ asked by a fellow member/nominating committee, $2.8 \%$ proposed by shareholders or shareholder groups, and $11 \%$ responded "other." Clearly, the senior management team remains an important element in the selection process. Approximately $47 \%$ did not know the CEO prior to being invited on the board, $29.4 \%$ knew the CEO as an acquaintance, $12.7 \%$ knew the CEO as a friend, $6.8 \%$ knew the CEO on another board, and $12.7 \%$ worked with the CEO at another company or nonprofit organization. Those with no prior affiliation with the company constituted $57.7 \%$ of the survey population. Of the remainder, $12.6 \%$ were former or current employees, $14.4 \%$ were customers or attorneys, $6.8 \%$ were consultants to the company and $4.5 \%$ previously dealt with the company as representatives of shareholder groups.

Our survey asked for the top three reasons board members were attracted to become a member and 64 respondents fully answered this question ranking first the challenge of the position $(31.2 \%)$, to learn $(26.6 \%)$, and to represent the interests of the shareholders (21.8\%). This is an interesting finding since it suggests that representing the interests of the shareholder was not the dominant reason a person accepted a directorship position. Also important is whether participants in our board survey were independent enough to turn down a board position and it is interesting that of the 108 responses to this question, 90 or $83.3 \%$, had previously refused a director position. The main reasons were time constraints (48.3\%), lack of confidence in the CEO (29.2\%), lack of interest in the company or industry $(27 \%)$, conflict of interest $(11.2 \%)$, and perceived personal risk (6.7\%) Apparently, directors were careful in balancing the gains from holding a director position with their personal and business needs. We also asked the participants if they had ever resigned from a board. Of the 107 who responded to this question, 50 directors $(49.5 \%)$ reported resigning from at least one board. The main reasons were lack of confidence in the CEO (43.3\%) time constraints (30.2\%), company taken over $(9.4 \%)$, not interested in company/industry (7.5\%), and conflict of interest (7.5\%). The survey collected data on the type of metrics directors used to evaluate performance of the firm, the CEO, and other directors. We asked survey participants to rank the top three metrics they used to evaluate firm performance and ninety one fully answered this question. The measures ranked 1 were rise in stock price/return (31 responses), increase in cash flow (18), increase in return on assets (15), increase in net income (15) and increase in market share (5). "Improved corporate social responsibilities" was ranked at the bottom of the list. The predominant criteria for evaluating performance were related to increasing shareholder value.

Survey participants were asked to rank the top three metrics used to evaluate other board members' performance. For the 87 people who answered this question, the measures ranked 1 were increased return on assets (27), increased stock price (26), greater responsiveness to shareholder concerns (21), and improved board/director independence (14). Corporate social responsibility had an aggregate score of 20 when all responses were added including those that were only partially answered and these responses suggest that board members evaluate each other primarily by the financial success of the company they oversee.

We also asked survey participants to rank the top three reasons for firing or removing a CEO. For the 91 who fully answered this question the measures ranked 1 were CEO's unethical conduct (61) and inaccurate financial reports (20). Poor profit performance was ranked among the top 3 reasons by 49 responders. Items like high level of employee turnover/dissatisfaction (23) and poor relationships with unions and/or government (5) were of much lower importance.

Sarbanes-Oxley increased the amount of time required to serve as a director or other member of the senior management team. The directors in our survey report spending 5.6 hours preparing for meetings, 7.6 hours at meetings, 2.0 hours talking with board members, 1.7 hours talking privately with the CEO, 0.4 hours talking with major shareholders and 0.8 on other board related matters. The amount of time spent with major shareholders is small in relation to talking with board members and the CEO but the total that a director spends each month exceeds 18 hours. A consequence is that non-retired directors must choose carefully which company to serve on and whether to serve on multiple boards. (Note 2)

With respect to stock ownership, seventy-one of 103 directors reported that they were required to hold a minimum amount of stock (68.9\%). The prevailing premise is that holding company stock creates an incentive for directors to more closely align their behavior with outcomes that increase shareholder value, thus reducing principle-agent problems associated with differences between ownership and control.

How important is it for a director to keep his position because of its effect on his income? This question is important because as suggested by Warren Buffet, if the compensation of directors is large enough it can create a desire for retaining one's position, even if this means compromising one's independence. The annual remuneration represented less than $10 \%$ of total income for 71 directors, $10-30 \%$ for $28,30-50 \%$ for 3 and over $50 \%$ for 2 . For most directors, the incremental 
earnings for board service were not large relative to other income. Most directors in the survey did not earn more than $30 \%$ of their income from their board position.

There were 101 useable returns to the survey question of the effect of Sarbanes_Oxley. The majority indicated that SOX substantially increased higher compliance costs (74), and improved internal controls (77). The next important effect given by the respondents was increased transparency (38). When we used the data for the 86 directors who provide full answers, the first two items are ranked 1. The responses ranked 2 were improved financial statements (12), increased decision making time (12), increased director liability (11), and increased transparency (13). The director responses suggest that SOX raised company costs but succeeded in providing increased transparency and remedying deficiencies in financial processes. This confirms the results of other studies such as Brick and Chidambaran (2010) which showed that SOX simultaneously increased current costs but also increased firm value due to the increased transparency.

We note that our survey questionnaire did not ask directors to reveal their names or the companies they work for in the interest of maintaining confidentiality. The feedback we received from the initial screening with our test set of directors indicated a reluctance to complete the survey in the absence of such confidentiality. We therefore are not able to conduct analysis at the firm level and they examine the valuation impact of director actions. Our focus is however on the importance of social networking to the level of board independence and our questionnaire meets those objectives.

\section{Measures of Independence and Stockholder Alignment}

In this section of the paper we focus on the alternative ways of measuring independence, shareholder alignment and concern for social responsibility that we develop based on the responses to the director survey. Table 2 provides the summary statistics of out independence, shareholder alignment and corporate citizenship measures.

Insert Table 2 about here

We begin with our metrics for director independence based on the prior connections that exist between the director and the $\mathrm{CEO}$ and the firm. We create four measures of independence based on the responses to Question \# 2 in the survey, specifically,

- Out_Nom: Director was not nominated by an insider of the firm but recommended by a search firm or proposed by shareholders.

-Not_Know_CEO: Director did not know the CEO prior to being invited to serve.

-Not_Affiiliated: Director was not previously affiliated with the company such as a previous employee, banker or general counsel to the CEO.

- All_Indep: Director was not nominated by an insider of the firm, did not know the CEO prior to being invited to serve and was not previously affiliated with the company.

In our sample, $54.7 \%$ are independent as defined by Out_Nom, $47.1 \%$ are independent as defined by Not_Know_CEO and $66.7 \%$ had no previous affiliation with the company. It is also plausible that a director may not have had a previous affiliation with a company, but may have previously known either the CEO or other top managers. Hence, we consider the more restrictive definition of All_Indep, of which $25 \%$ of our directors fall under this category.

Our survey elicits responses from directors that can also be used to measure their alignment with stockholder interests. We create three measures of alignment based on the responses to Questions \# 5, 12 and 13 in the survey. Specifically,

Specifically we create three measures of alignment

- Align_ROB: Reason director is on the board is to represent shareholder interests (Q5)

- Align_EvalFirm: Director uses stock returns to evaluate firm performance (Q12)

-Align_EvalDir: Director will use stock returns performance to evaluate other directors (Q13)

In response to Question 5, 44 of the 104 director responses, or 42.3\%, mention that representing shareholder interests was one of the top 3 criteria for accepting the job. In response to Question 12, 69 of 102 director responses, or $76.4 \%$, indicate that the director would use profitability metrics to evaluate the firm. Finally, 60 of 103 directors, or $58.3 \%$, would use stock performance to evaluate their fellow directors. We examine the impact of our board independence proxies on our alignment measures to test Hypothesis 1 and expect a positive association between board independence and our alignment measures. 
To measure their concern for corporate citizenship and the firm's contribution to society, we develop the following measures.

- Citz_ROB: Reason director is on board is to contribute to society (Q5)

-Citz_EvalFirm: Director uses social responsibility/citizenship to evaluate firm performance (Q12)

- Citz_EvalDir: Director uses social responsibility/citizenship to evaluate other directors (Q13).

In response to Question 5, 15 of the 103 director responses, or $14.6 \%$, mention that contributing to society was one of the top 3 criteria for accepting the job. In response to Question 12, 10 of 102 director responses, or $9.8 \%$, indicate that the director would use social responsibility/citizenship contributions to evaluate the firm. Finally, 20 of 103 directors, or $19.4 \%$, would use social responsibility/citizenship contributions to evaluate their fellow directors. We examine the impact of our board independence proxies on our citizenship measures to test Hypothesis 3. If independent directors are overly concerned about shareholder value, then they might display a low concern for other stakeholders of the firm.

\section{Results}

In this section, we apply the definitions to determine whether independent directors differ in their actions directors for insider directors, where independence is defined based on the social network between directors and the CEO. In each of our tests reported below we test the percentage differences using the rank-sum Wilcoxon test. Our tables report the raw $\mathrm{Z}$ scores and the statistical significance.

\subsection{Evaluation of the $C E O$}

The decision to fire CEO is a painful one and it is not lightly made. We examine whether independent and non-independent directors differ in their use of stock performance and ethical lapses by the CEO as reasons for removing the CEO. Business ethics can be defined as the written or informal codes of principles and values that govern decisions and actions within a company and there is common agreement that both ethical principles and values are set at the top with oversight responsibility expected of the CEO and the board. Typically, a company's culture sets the framework used to separate good and bad decision making and behavior and this is affected significantly by the actions, attitudes, and beliefs of the $\mathrm{CEO}$ and the corporate directors.

Table 3, Panel A shows the results of our analysis of the CEO replacement decision assuming that poor stock performance is one of the top three reasons to replace the CEO. We find that independent directors, as proxied by not having been nominated by an insider are more likely to fire the $\mathrm{CEO}$ or poor stock return performance.

Insert Table 3 about here

Table 3, Panel B, investigates whether there is a difference between the percentages of independent and non-independent directors who cite ethical lapses as the top reason for firing the CEO. Our results indicate that there is no significant difference in the likelihood of replacing the CEO for ethical lapses between independent and non-independent directors. Although statistically insignificant, in all cases we find that independent directors are more likely to fire the CEO for ethical lapses than insider directors.

\subsection{Corporate Social Responsibility and Director Independence}

Boards have been criticized for not considering the societal impact of corporate decisions. Some ethicists believe that companies should consider the needs of all its stakeholders, not simply those with a financial stake in the enterprise. For them, the term corporate social responsibility suggests that ethical business decisions should be based on how they work for the good of all a business's constituency groups, factoring in social issues like sustainability, climate, and evaluation of boards using social criteria.

It is noteworthy that directors report ethics are a frequent part of boardroom discussions and introduced as a conscious part of the agenda (93 responses of a possible 102). However, the findings from our survey indicate a majority of the directors studied place a decisively lower priority on corporate social responsibility. That discussion of ethics is more prominent, than that of social responsibility, in the boardroom is not surprising since ethical issues are somewhat easier to identify, gain consensus on, and monitor than are social responsibility issues.

An interesting ancillary hypothesis worth examining is that if independent directors are overly concerned about shareholder value, then they might display a low concern for other stakeholders of the firm. We therefore examine whether the independent and non-independent directors differ in their concern for social responsibility, as proxied by the corporate 
social responsibility/citizenship metrics we have developed (see previous section, Section 4), in evaluating firm performance and the effectiveness of fellow directors. Table 4 summarizes the results. We find no evidence that independent directors care less about social responsibility than do non-independent directors.

Insert Table 4 about here

A plausible reason for the lack of a difference in social responsibility concerns between independent and dependent directors is that there is a substantial awareness campaign about a corporation's social responsibility. This could result in a cognitive positive bias toward social responsibility for all directors, both dependent and independent.

\subsection{Compensation and Director Independence}

Warther (1998) and Brick et al (2006) suggest that high director compensation impairs the director's ability to independently monitor management activities. We examine whether the percentage of director's annual income derived from the firm is different between independent and non-independent directors to test Hypothesis 2 . Table 5 shows that independent directors receive a lower percentage of their income from being a director of the firm than do non-independent directors. We conclude therefore that directors that are independent by our metrics are less likely to be compromised due to compensation.

Insert Table 5 about here

\subsection{Director Activities and Independence}

The survey asks the directors the type of tasks they undertake as a member of the board. The most frequently cited activities of the board are (a) evaluation of the strategic plan, (b) participating in meetings without the CEO and (c) evaluating the company's ethical standards. We tabulate the number of activities that the director reports and label a director as active if the director was involved in 5 or more activities. Of the 106 directors who responded to this question, $68(64 \%)$ of the respondents are active by this definition. As Table 7 reports. We find that insider nominated directors are more active than other directors, a result consistent with the findings of Westphal (1999). We note, however, we find no differences in the number of hours worked by independent and non-independent directors.

Insert Table 6 about here

\section{Conclusions}

Recent trends in director nomination and selection largely ensure that individuals elected as directors meet the independence criteria laid down by the Securities and Exchange Commission. We argue CEOs and independent directors belong to social networks, which add additional dimensions to the nominal notion of independence. Social connection between the director candidates can compromise the independence of the director leading to need to rethink director independence.

Based on a national survey conducted in 2006-2007, this paper finds evidence that the directors in our study indeed have strong ties to the CEO and the company. A majority of board members knew the CEO prior to becoming a director, were recommended for their positions by top management and/or had prior affiliations with the firm. By these measures, boards are far less independent compared to independence levels of $80 \%$ when measured by the traditional metrics of independence. We examine the impact of these alternate definitions of independence that incorporate social connections between the director and the board member.

We find that the independent directors, those who are not nominated by company insiders, are more likely to hold the CEO responsible for poor performance and are less likely to receive much of their compensation from the directorship. We also find that such outsider-nominated directors are as likely as insider-nominated directors to express a concern about corporate citizenship or ethical misconduct by the CEO. We also find that ethics are an important part of their thinking with more than $90 \%$ of the directors reporting that ethics were discussed at boardroom meetings and $61 \%$ of directors report that inappropriate ethical behavior by the $\mathrm{CEO}$ is an important reason to fire the CEO. 
Our survey and results shows that unmeasured board attributes with respect to the networks between boards and management have an important bearing on the board's operation and their monitoring and advising roles. These findings have important implications for the process by which directors are elected and the structure and composition of corporate boards. Our findings, for example, validate efforts to have director nominees provide detailed biographies to shareholders and report on affiliations with the firm, when they stand for election so that shareholders can be informed about some of these informal links. Further research is clearly indicated on the corporate impact of social networks between Directors and the management.

\section{References}

Adams, R., Ferreira, D. (2007). A theory of friendly boards, Journal of Finance, 62, 217-250. http://dx.doi.org/10.1111/j.1540-6261.2007.01206.x

Blue Ribbon Committee on Improving the Effectiveness of Corporate Audit Committees (1999). Report and Recommendation, NYSE and Nasdaq.

Beasley, M. (1996). An empirical analysis of the relation between the board of director composition and financial statement fraud, Accounting Review, 71: 443-465.

Brick, I., Chidambaran, N. K. (2010). Board meetings, committee structure, and firm value, Journal of Corporate Finance, 16: 533-553. http://dx.doi.org/10.1016/j.jcorpfin.2010.06.003

Brick, I., Palmon O., Wald, J. (2006). CEO compensation, director compensation, and firm performance: Evidence of cronyism?, Journal of Corporate Finance, 12: 403-423. http://dx.doi.org/10.1016/j.jcorpfin.2005.08.005

Byrd, J. and K. Hickman, (1992). Do outside directors monitor managers? Evidence from tender offer bids, Journal of Financial Economics, 32: 195-221. http://dx.doi.org/10.1016/0304-405X(92)90018-S

Chidambaran, N. K., Kedia, S., Prabhala, N. R. (2011). CEO-director connections and corporate fraud, Working Paper, Fordham University.

Cohen, L., Frazzini, A., Malloy, C. (2008). The Small World of Investing: Board Connections and Mutual Fund Returns, Journal of Political Economy, 116, 951-979. http://dx.doi.org/10.1086/592415

Cohen, L., Frazzini, A., Malloy, C. (2010). Sell Side School Ties, Journal of Finance, 65, 1409-1437. http://dx.doi.org/10.1111/j.1540-6261.2010.01574.x

Corporate Board Members Magazine and Price Waterhouse Coopers (2008). What Directors Think: Annual Board Survey.

Cotter, J. F., Shivdasani, A., Zenner, M. (1997). Do independent directors enhance target shareholder wealth during tender offers? Journal of Financial Economics, 43, 195-218. http://dx.doi.org/10.1016/S0304-405X(96)00886-0

Healy, P. M., Palepu, K. G. (2003). The fall of Enron, Journal of Economic Perspectives, 17: 3 -26. http://dx.doi.org/10.1257/089533003765888403

Klein, A. (2002). Audit committee, board of director characteristics, and earnings management, Journal of Accounting and Economics, 3: 375-400. http://dx.doi.org/10.1016/S0165-4101(02)00059-9

Lorsch, J. L., MacIver, E. M. (1989). Pawns or Potentates? The Reality of America's Corporate Boards, Harvard Business Press, Boston.

Payne, G. T., Benson, G. S., Finegold, D. L. (2009). Corporate board attributes, team effectiveness and financial performance, Journal of Management Studies, 46: 704-731. http://dx.doi.org/10.1111/j.1467-6486.2008.00819.x

Roy, M. (2009). Linking board types to key board roles, International Journal of Business Governance and Ethics, 4: 298-314. http://dx.doi.org/10.1504/IJBGE.2009.023334

Schaffer, B. (2002). Board assessments of managerial performance: An analysis of attribution processes, Journal of Managerial Psychology, 17: 95 - 115. http://dx.doi.org/10.1108/02683940210417030

Stevenson, W. B., Radin, R. F. (2009). Social capital and social influence on the board of directors, Journal of Management Studies,46, 16-44. http://dx.doi.org/10.1111/j.1467-6486.2008.00800.x

Warther, V. A. (1998). Board Effectiveness and Board Dissent: A Model of the Board's Relationship to Management and Shareholders, Journal of Corporate Finance, 4, 53-70. http://dx.doi.org/10.1016/S0929-1199(97)00009-6

Westphal, J. (1999). Collaboration in the boardroom: Behavioral and performance consequences of CEO-Board social ties, Academy of Management Journal, 42, 7-24. http://dx.doi.org/10.2307/256871

Weisbach, M. (1988). Outside directors and CEO turnover, Journal of Financial Economics, 20, 431-460. http://dx.doi.org/10.1016/0304-405X(88)90053-0 
Notes

Note 1 . We had at least $20 \%$ errors in the addresses obtained through the Corporate Library. Correcting for these errors, we find the response rate online consistent with other surveys.

Note 2. The increasing concern with respect to the impact of regulation and demands on the time commitment by board members is also consistent with the results of the 10th annual legal study by Corporate Board Member and FTI Consulting, Inc. The study was based upon survey sent to 8,500 directors and to 2,252 general counsel during January 2010.

Table 1. Director Biographical Data

\begin{tabular}{lccc}
\hline & $\begin{array}{c}\text { Directors } \\
\text { Choosing Criteria }\end{array}$ & $\begin{array}{c}\text { Total \# of Director } \\
\text { Responding to Question }\end{array}$ & Percentage \\
\hline Position On Board & & 103 & $12.62 \%$ \\
\hline Chairman & 13 & 103 & $5.83 \%$ \\
\hline Vice Chair & 6 & 103 & $1.94 \%$ \\
\hline Lead Director & 2 & 103 & $68.93 \%$ \\
\hline Director & 71 & 103 & $8.74 \%$ \\
\hline Audit Committee & 9 & 103 & $1.94 \%$ \\
\hline CEO & 2 & & \\
\hline
\end{tabular}

\section{Education}

\begin{tabular}{lccc}
\hline High School & 1 & 108 & $0.93 \%$ \\
\hline BA/BS & 29 & 108 & $26.85 \%$ \\
\hline Masters & 35 & 108 & $32.41 \%$ \\
\hline MD & 1 & 108 & $0.93 \%$ \\
\hline JD & 20 & 108 & $18.52 \%$ \\
\hline PhD & 22 & 108 & $20.37 \%$ \\
\hline
\end{tabular}

Field of Study

\begin{tabular}{lccc}
\hline Finance & 14 & 108 & $13.46 \%$ \\
\hline Accounting & 8 & 108 & $7.69 \%$ \\
\hline Business & 30 & 108 & $28.85 \%$ \\
\hline Law & 20 & 108 & $19.23 \%$ \\
\hline Engineering & 10 & 108 & $9.62 \%$ \\
\hline Science & 5 & 108 & $4.81 \%$ \\
\hline Education & 4 & 108 & $3.85 \%$ \\
\hline Public admin & 1 & 108 & $0.96 \%$ \\
\hline Economics/Political Sci & 9 & 108 & $8.65 \%$ \\
\hline Medicine & 1 & 108 & $0.96 \%$ \\
\hline Government & 1 & 108 & $0.96 \%$ \\
\hline Political science & 1 & 108 & $0.96 \%$ \\
\hline
\end{tabular}

\begin{tabular}{|c|c|c|c|c|c|c|}
\hline Variable & $\mathrm{N}$ & Mean & Median & Std Dev & Min & $\operatorname{Max}$ \\
\hline Numbds & 102 & 1.57 & 1 & 1.77 & 0 & 12 \\
\hline $\begin{array}{l}\text { Total Experience (Years) } \\
\text { on Boards }\end{array}$ & 104 & 18.2 & 15 & 15 & 0 & 100 \\
\hline Years on Current Board & 106 & 9.63 & 7 & 8.44 & 1 & 56 \\
\hline Total Skills & 107 & 5.98 & 6 & 2.3 & 1 & 13 \\
\hline
\end{tabular}


Table 2. Independence, Alignment, and Social Responsibility

The table shows the number of directors who are independent, the number of directors who are concerned about corporate citizenship/social responsibility, and the number of directors who are aligned with shareholders in our survey sample. We develop three variables that measure of independence, three variables that measure stockholder alignment, and three variables that indicate good citizenship/social responsibility, based on our survey of corporate directors. Definitions of our variables are found in Section 4.

\begin{tabular}{lccc}
\hline Variable & $\begin{array}{c}\text { \# Directors With } \\
\text { Attribute }\end{array}$ & $\begin{array}{c}\text { Total \# of Director } \\
\text { Responding to Question }\end{array}$ & Percentage \\
\hline Independence Measures & & & \\
\hline Not_Know_CEO & 48 & 103 & $46.6 \%$ \\
\hline Out_Nom & 33 & 102 & $32.4 \%$ \\
\hline Not_Aff & 67 & 98 & $65.7 \%$ \\
\hline All_Indep & 24 & & $24.5 \%$ \\
\hline & & & \\
\hline $\begin{array}{l}\text { Shareholder Alignment } \\
\text { Measures }\end{array}$ & & & \\
\hline Align_ROB & 44 & 104 & $62.3 \%$ \\
\hline Align_EvalFirm & 69 & 102 & $58.3 \%$ \\
\hline Align_EvalDir & 60 & 103 & \\
\hline & & & \\
\hline Citizenship/Social & & & $14.6 \%$ \\
Responsibility Measures & & 103 & $9.8 \%$ \\
\hline Citz_ROB & 15 & 102 & $19.4 \%$ \\
\hline Citz_EvalFirm & 10 & 103 & \\
\hline Citz_EvalDir & 20 & & \\
\hline
\end{tabular}

Table 3. CEO replacement and Director Independence

This table reports on the relationship between the criterion directors use to replace the CEO and director independence based on our survey. Panel A reports data when directors use shareholder value metrics as one of the top three reasons for firing the CEO. Panel B reports data when directors use ethical lapses as the top reason for firing the CEO. In each panel, Columns 1, 2, and 3 report the number of non-independent directors that use the metric for firing the CEO, the total number of non-independent directors, and the percentage of non-independent directors that use the metric for firing the $\mathrm{CEO}$, respectively. Columns 4, 5, and 6 in each panel report the number of independent directors that use the metric for firing the CEO, the total number of independent directors, and the percentage of independent directors that use the metric for firing the CEO, respectively. Columns 7 and 8 in the panels report the Wilcoxon Z-statistic for the difference in the percentage of non-independent and independent directors who use the metric and the p-values, respectively, with statistically significant values in bold..

Panel A: Shareholder Concern

\begin{tabular}{|c|c|c|c|c|c|c|c|}
\hline $\begin{array}{l}\text { Director Used } \\
\text { Stock Criteria }\end{array}$ & $\mathrm{N}$ & $\%$ & $\begin{array}{l}\text { Director Used } \\
\text { Stock Critera }\end{array}$ & $\mathrm{N}$ & $\%$ & Z & Pval \\
\hline \multicolumn{3}{|c|}{ Not_Know_CEO=0 } & \multicolumn{3}{|c|}{ Not_Know_CEO=1 } & \multicolumn{2}{|c|}{ Wilcoxon } \\
\hline 32 & 51 & $63 \%$ & 33 & 44 & $75 \%$ & -1.275 & 0.203 \\
\hline \multicolumn{3}{|c|}{ OutNom $=0$} & \multicolumn{3}{|c|}{ OutNom $=1$} & \multicolumn{2}{|c|}{ Wilcoxon } \\
\hline 39 & 65 & $60 \%$ & 25 & 29 & $86 \%$ & -2.504 & 0.012 \\
\hline \multicolumn{3}{|c|}{ Not_Aff $=0$} & \multicolumn{3}{|c|}{ Not_Aff $=1$} & \multicolumn{2}{|c|}{ Wilcoxon } \\
\hline 20 & 33 & $61 \%$ & 44 & 62 & $71 \%$ & -1.020 & 0.308 \\
\hline \multicolumn{3}{|c|}{ All_Indep $=0$} & \multicolumn{3}{|c|}{ All Indep $=1$} & \multicolumn{2}{|c|}{ Wilcoxon } \\
\hline 43 & 69 & $62 \%$ & 19 & 22 & $86 \%$ & -2.096 & $\overline{0.036}$ \\
\hline
\end{tabular}


Panel B: Ethical Concerns

\begin{tabular}{|c|c|c|c|c|c|c|c|}
\hline $\begin{array}{l}\text { Director Used } \\
\text { Ethics Critera }\end{array}$ & $\mathrm{N}$ & $\%$ & $\begin{array}{l}\text { Director Used } \\
\text { Ethics Critera }\end{array}$ & $\mathrm{N}$ & $\%$ & Z & Pval \\
\hline \multicolumn{3}{|c|}{ Not Know $C E O=0$} & \multicolumn{3}{|c|}{ Not Know $C E O=1$} & \multicolumn{2}{|c|}{ Wilcoxon } \\
\hline 34 & 51 & $67 \%$ & 32 & 44 & $73 \%$ & -0.636 & 0.525 \\
\hline \multicolumn{3}{|c|}{ OutNom $=0$} & \multicolumn{3}{|c|}{ OutNom $=1$} & \multicolumn{2}{|c|}{ Wilcoxon } \\
\hline 44 & 65 & $68 \%$ & 21 & 29 & $72 \%$ & -0.455 & 0.649 \\
\hline \multicolumn{3}{|c|}{ Not_Aff $=0$} & \multicolumn{3}{|c|}{ Not Aff $=1$} & \multicolumn{2}{|c|}{ Wilcoxon } \\
\hline 21 & 33 & $64 \%$ & 43 & 62 & $69 \%$ & -0.563 & 0.573 \\
\hline \multicolumn{3}{|c|}{ All_Indep } & \multicolumn{3}{|c|}{ All Indep } & \multicolumn{2}{|c|}{ Wilcoxon } \\
\hline 47 & 69 & $68 \%$ & 15 & 22 & $68 \%$ & -0.006 & 0.995 \\
\hline
\end{tabular}

Table 4. Social Responsibility and Director Independence

This table reports on the relationship between the criterion directors use to evaluate the firm and other directors and director independence based on our survey. Panel A reports data when directors use social responsibility metrics as one of the top three reasons for evaluating the firm. Panel B reports data when directors use social responsibility metrics as the top reason for evaluating other directors. In each panel, Columns 1, 2, and 3 report the number of non-independent directors that use social responsibility metrics for evaluation, the total number of non-independent directors, and the percentage of non-independent directors that use the social responsibility metrics for evaluation, respectively. Columns 4, 5, and 6 in each panel report the number of independent directors that use social responsibility metrics for evaluation, the total number of independent directors, and the percentage of independent directors that use the social responsibility metrics for evaluation, respectively. Columns 7 and 8 in the panels report the Wilcoxon Z-statistic for the difference in the percentage of non-independent and independent directors who use the metric and the p-values, respectively, with statistically significant values in bold.

Panel A: Evaluating the firm

\begin{tabular}{|c|c|c|c|c|c|c|c|}
\hline Citz_EvalFirm & $\mathrm{N}$ & $\%$ & Citz EvalFirm & $\mathrm{N}$ & $\%$ & $\mathrm{Z}$ & Pval \\
\hline \multicolumn{3}{|c|}{ Not_Know_CEO $=0$} & \multicolumn{3}{|c|}{ Not_Know_CEO $=1$} & \multicolumn{2}{|c|}{ Wilcoxon } \\
\hline 6 & 52 & $12 \%$ & 3 & 44 & $7 \%$ & 0.786 & 0.432 \\
\hline \multicolumn{3}{|c|}{ OutNom $=0$} & \multicolumn{3}{|c|}{ OutNom $=1$} & \multicolumn{2}{|c|}{ Wilcoxon } \\
\hline 7 & 66 & $11 \%$ & 2 & 29 & $7 \%$ & 0.566 & 0.572 \\
\hline \multicolumn{3}{|c|}{ Not_Aff $=0$} & \multicolumn{3}{|c|}{ Not_Aff $=1$} & \multicolumn{2}{|c|}{ Wilcoxon } \\
\hline 4 & 35 & $11 \%$ & 5 & 61 & $8 \%$ & 0.520 & 0.825 \\
\hline \multicolumn{3}{|c|}{ All_Indep $=0$} & \multicolumn{3}{|c|}{ All_Indep $=1$} & \multicolumn{2}{|c|}{ Wilcoxon } \\
\hline 7 & 71 & $10 \%$ & 2 & 21 & $10 \%$ & 0.045 & 0.964 \\
\hline
\end{tabular}

Panel B: Evaluating other director

\begin{tabular}{|c|c|c|c|c|c|c|c|}
\hline Citz_EvalDir & $\mathrm{N}$ & $\%$ & Citz_EvalDir & $\mathrm{N}$ & $\%$ & $\mathrm{Z}$ & Pval \\
\hline \multicolumn{3}{|c|}{ Not Know $C E O=0$} & \multicolumn{3}{|c|}{ Not Know $C E O=1$} & \multicolumn{2}{|c|}{ Wilcoxon } \\
\hline 13 & 53 & $25 \%$ & 6 & 44 & $14 \%$ & 1.339 & 0.181 \\
\hline \multicolumn{3}{|c|}{ OutNom $=0$} & \multicolumn{3}{|c|}{ OutNom $=1$} & \multicolumn{2}{|c|}{ Wilcoxon } \\
\hline 16 & 67 & $24 \%$ & 3 & 29 & $10 \%$ & 1.520 & 0.128 \\
\hline \multicolumn{3}{|c|}{ Not_Aff $=0$} & \multicolumn{3}{|c|}{ Not_Aff $=1$} & \multicolumn{2}{|c|}{ Wilcoxon } \\
\hline 5 & 34 & $15 \%$ & 11 & 63 & $17 \%$ & -0.347 & 0.729 \\
\hline \multicolumn{3}{|c|}{ All_Indep } & \multicolumn{3}{|c|}{ All_Indep } & \multicolumn{2}{|c|}{ Wilcoxon } \\
\hline 14 & 71 & $20 \%$ & 2 & 22 & $9 \%$ & 1.148 & 0.251 \\
\hline
\end{tabular}


Table 5. Compensation and Director Independence

This table reports on the relationship between compensation and director independence based on our survey. High Comp is a dummy variable that is equal to one if the compensation received as a director is more than $10 \%$ of the director's total annual income. Columns 1, 2, and 3 report the number of non-independent directors when High Comp is one, the total number of non-independent directors, and the percentage of non-independent directors with High Comp equal to one, respectively. Columns 4, 5, and 6 report the number of independent directors with High Comp equal to one, the total number of independent directors, and the percentage of independent directors with High Comp equal to one, respectively. Columns 7 and 8 report the Wilcoxon Z-statistic for the difference in the percentage of non-independent and independent directors who have High Comp and the p-values, respectively, with statistically significant values in bold.

\begin{tabular}{|c|c|c|c|c|c|c|c|}
\hline High Comp & $\mathrm{N}$ & $\%$ & High Comp & $\mathrm{N}$ & $\%$ & $\mathrm{Z}$ & Pval \\
\hline \multicolumn{3}{|c|}{ Not Know $C E O=0$} & \multicolumn{3}{|c|}{ Not Know $C E O=1$} & \multicolumn{2}{|c|}{ Wilcoxon } \\
\hline 21 & 55 & $38 \%$ & 10 & 45 & $22 \%$ & 1.708 & 0.088 \\
\hline \multicolumn{3}{|c|}{ OutNom $=0$} & \multicolumn{3}{|c|}{ OutNom $=1$} & \multicolumn{2}{|c|}{ Wilcoxon } \\
\hline 26 & 69 & $38 \%$ & 5 & 30 & $17 \%$ & 2.061 & 0.040 \\
\hline \multicolumn{3}{|c|}{ Not $A f f=0$} & \multicolumn{3}{|c|}{ Not_Aff $=1$} & \multicolumn{2}{|c|}{ Wilcoxon } \\
\hline 9 & 35 & $26 \%$ & 21 & 65 & $32 \%$ & -0.683 & 0.495 \\
\hline \multicolumn{3}{|c|}{ All Indep $=0$} & \multicolumn{3}{|c|}{ All Indep $=1$} & \multicolumn{2}{|c|}{ Wilcoxon } \\
\hline 25 & 74 & $34 \%$ & 5 & 22 & $23 \%$ & 0.977 & 0.329 \\
\hline
\end{tabular}

Table 6. Board Activity and Director Independence

This table reports on the relationship between a director's activity level and independence based on our survey. Active is a dummy variable that is one if a director is active and zero otherwise. Active is set equal to 1 when a director is involved in five or more activities and is zero otherwise, based on the director's response to Question 11 in our survey. Columns 1, 2, and 3 report the number of non-independent directors who are active, the total number of non-independent directors, and the percentage of non-independent directors who are active, respectively. Columns 4, 5, and 6 report the number of independent directors who are active, the total number of independent directors, and the percentage of independent directors who are active, respectively. Columns 7 and 8 report the Wilcoxon Z-statistic for the difference in the percentage of non-independent and independent directors who are active and the p-values, respectively, with statistically significant values in bold.

\begin{tabular}{|c|c|c|c|c|c|c|c|}
\hline Active & $\mathrm{N}$ & $\%$ & Active & $\mathrm{N}$ & $\%$ & Z & Pval \\
\hline \multicolumn{3}{|c|}{ Not_Know_CEO $=0$} & \multicolumn{3}{|c|}{ Not_Know_CEO=1 } & \multicolumn{2}{|c|}{ Wilcoxon } \\
\hline 37 & 54 & $69 \%$ & 26 & 47 & $55 \%$ & 1.359 & 0.174 \\
\hline \multicolumn{3}{|c|}{ OutNom $=0$} & \multicolumn{3}{|c|}{ OutNom $=1$} & \multicolumn{2}{|c|}{ Wilcoxon } \\
\hline 47 & 68 & $69 \%$ & 15 & 32 & $47 \%$ & 2.127 & 0.033 \\
\hline \multicolumn{3}{|c|}{ Not Aff $=0$} & \multicolumn{3}{|c|}{ Not_Aff $=1$} & \multicolumn{2}{|c|}{ Wilcoxon } \\
\hline 22 & 35 & $63 \%$ & 42 & 65 & $65 \%$ & -0.174 & 0.8620 \\
\hline \multicolumn{3}{|c|}{ All_Indep $=0$} & \multicolumn{3}{|c|}{ All_Indep $=1$} & \multicolumn{2}{|c|}{ Wilcoxon } \\
\hline 49 & 73 & $67 \%$ & 11 & 23 & $48 \%$ & 1.658 & 0.097 \\
\hline
\end{tabular}




\section{Appendix:}

\section{Survey of Corporate Directors}

\section{Instructions:}

If you serve on multiple boards, you may fill out this survey multiple times. Each time answer all questions with respect to a single board.

Please answer sequentially and note that you cannot save and restart the survey. If you go back to the survey, it will be treated as a separate response.

\section{Biographical Information:}

Position on the board (e.g., Chairman, Lead Director, Director)

The number of years on this board:

Number of other corporate boards currently serving

Total experience (in years) serving on any corporate board

Highest degree obtained:

Field of study of highest degree:

Finance ___ Accounting __ Business___Law___Engineering___ Science___Education Public Administration Economics Medicine Government Political Science

1) What skills do you bring to this position (Please check all that apply):

Strategic planning

Financial analysis

Advertising/Marketing

Merger \& Acquisition skills

Scientific training

Operations/ Project management skills

Lobbying/Public relations

Regulatory compliance experience

Networking skills/Strong contact base

Competitive intelligence

Legal

Organizational restructuring

Problem solving

Other

\section{2) How were you selected as a director? (Please check all that apply)}

Invited by senior management

Suggested by a search firm

Asked by a fellow board member/Nominating committee

Proposed by shareholders or shareholder group

Other

3) How would you describe your relationship with the CEO prior to your joining the board?

Didn't Know_CEO 
Knew $\mathrm{CEO}$ as an acquaintance

Knew CEO as a friend

Knew CEO on another board

Worked with CEO at another company/non-profit organization

4) Do you have an affiliation with the company in any of the following ways? (Check all items that apply)

No affiliation

Former or current employee

Former or current customer

Former or current attorney/counsel

Former or current auditor

Former or current banker/financier

Former or current supplier

Former or current regulator

Former or current consultant to firm

Deal with firm as representative of major shareholder group

Other

5) Rank the three most important reasons that you accepted the director position? (Rank 1 most important and 3 the least)

The challenge

To learn

The prestige

The remuneration

To contribute to society

To work with the CEO

To increase business contacts

To do partial work during retirement

Represent interests of shareholders

Represent employees

To create synergies between this company and another

Other

6) Have you ever refused a directorship position? Yes

No

\section{7) If yes, what was the main reason for your refusal?}

Not interested in company/industry

Conflict of interest

Lack of confidence in the CEO/company

Poor compensation

Time constraints

Personal health

Perceived personal risk

Other

8) Have you ever resigned from a board?

Yes

No

9) If yes, what was your main reason for doing so?

Not interested in company/industry

Conflict of interest

Lack of confidence in the CEO/company 
Poor compensation

Time constraints

Personal health

Concern with liability exposure

Company was taken over

Other

10) What due diligence did you undertake prior to accepting your directorship? (Please check all that apply)

Talked to other board members at company

Talked to lead director

Talked to chair of board

Talked to past directors

Talked to major suppliers/customers of company

Talked to my attorney(s)

Talked to board attorney

Examined financial statements

Examined analyst reports on the firm

Researched company's relative performance

Other

11) For each item, check if you....

Make recommendations for agenda items for board as a whole

Evaluate other directors

without CEO present

Evaluate and propose changes in the strategic plan

Discuss and evaluate company's ethical standards

Speak with major shareholders/institutions

Run executive session

12) Rank the three most important measures in evaluating the company's performance (Rank 1 most important and 3 least):

Rise in stock price/return

Increase in customer base

Increase in return on assets

Increase in cash flow

Increase in net income

Improved corporate social responsibility/citizenship

Increase in market share

Other (please specify)

13) Rank the three most important measures in evaluating board of director's effectiveness (Rank 1 most important and 3 least):

Increase in return on assets

Increase in stock returns

Increase in company's market share

Improved employee loyalty

Greater responsiveness to shareholder concerns

Improved board/director independence

Improved ratings from analysts

Improved corporate social responsibility/citizenship

Other (please specify) 
14) Rank the three most important reasons to consider removing the CEO from his position (Rank 1 most important and 3 least):

Poor stock price performance

High level of employee turnover/dissatisfaction

Poor profit performance

CEO's poor relationship with union/public/government

CEO's style of management

Inaccurate financial reports

CEO's ethical conduct

Other (please specify)

15) What sources of information do you use, as a board member, for decision making? (Please check all that apply):
Senior management
Internal auditors
External auditors
General counsel
Consultants
Financial analysts
Internet/Media sources
Institutional investors
Rating agencies
Employees
Other (please specify)

16) Approximately, how many hours do you spend each month on the following?

Preparing for meetings

At meetings

Talking with other board members

Talking privately with the CEO

Talking with major shareholders

Other (Please specify)

Total

17) Are you required to own a minimum amount of stock (excluding options) in this company? Yes

No

18) What percentage does your annual remuneration from this board position represent of your total annual income?

Less than $10 \%$

$10 \%-30 \%$

$30 \%-50 \%$

Over $50 \%$

19) Who evaluates you as a director? (Please check all that apply)

Other board members

$\mathrm{CEO}$ and/or other top management

External consultants

Chair of Board (if not CEO)

Lead Director

Major shareholders 
Governance rating agencies

Not Evaluated

Other

20) In your view, what are the three most important effects of Sarbanes-Oxley legislation? (Rank 1 most important and 3 least):

Improved financial statements

Improved internal controls

Substantially higher compliance costs

Increased decision making time

Increased director liability

Increased transparency

Increased shareholder value

Better quality directors

Other (Please specify)

21) Which of these is part of the boardroom discussions? (Please check all that apply)

Ethics

Director's relationship with internal audit

Processes for employees to provide information

on company/management performance to board

Formal limits on meeting length

Formal limits on number of other boards a director can serve on

22) Board agenda items for the past fiscal year (please check all that apply):

Approval for issuing equity

Approval for issuing debt

Approval for acquisitions/mergers

Approval of licensing with other company

Approval of major asset acquisition or divestiture

Approval of sale of division

Equity compensation plans

Replacement of CEO

Approval of spin off

Approval of charter amendments

Compliance with Sarbanes Oxley

Succession planning

\section{Other}

23) Please check all of the following that reflect your participation in board activities during this past year.

You worked individually on specific initiatives proposed by board

You worked on ad hoc projects with other board members

You made suggestions to improve financial reporting

You suggested changes to company policies and/or procedures

You met privately with the $\mathrm{CEO} / \mathrm{CFO}$ on strategic matters

You proposed initiatives to improve internal audit

You recommended individuals for key management positions

You made suggestions to change firm governance

Thank you. We deeply appreciate your assistance in acquiring these important pieces of information 